Abstracta Iranicacta Iranica

Revue bibliographique pour le domaine irano-aryen

Volume 28 | 2007

Comptes rendus des publications de 2005

\title{
« An Account Tablet from Eighth-Century Khotan ». BAI 15, 2001 [2005], pp. 1-8.
}

\section{Mauro Maggi}

\section{(2) OpenEdition}

1 Journals

\section{Édition électronique}

URL : http://journals.openedition.org/abstractairanica/10252

DOI : 10.4000/abstractairanica.10252

ISSN : 1961-960X

Éditeur :

CNRS (UMR 7528 Mondes iraniens et indiens), Éditions de l'IFRI

\section{Édition imprimée}

Date de publication : 15 mai 2007

ISSN : 0240-8910

\section{Référence électronique}

Mauro Maggi, « «An Account Tablet from Eighth-Century Khotan ». BAl 15, 2001 [2005], pp. 1-8. », Abstracta Iranica [En ligne], Volume 28 | 2007, document 27, mis en ligne le 18 septembre 2007,

consulté le 25 septembre 2020. URL : http://journals.openedition.org/abstractairanica/10252 ; DOI : https://doi.org/10.4000/abstractairanica.10252

Ce document a été généré automatiquement le 25 septembre 2020.

Tous droits réservés 


\title{
«An Account Tablet from Eighth- Century Khotan ». BAI 15, 2001 [2005], pp. 1-8.
}

\author{
Mauro Maggi
}

1 Edition, translation, commentary and facsimiles of a new Khotanese wooden document concerning expenditure of grain and containing several previously unattested words. Skjærvø reads in ll. 2-4 the month names Rarūya, Hamidyaja and Ttumjāra "although this would be the wrong order" (p. 1), Hamdyaja and Rarūya being the first and second summer months respectively. I would suggest the following readings with a regular sequence of months: (2) [ra]rūyä māśtä 'in the month of Rarūya', (3) [ttum]jjārä māśtä 'in the month of Ttumjāara', and (4) [śi'ye] ttu[ṃ]jārä māśtä 'in the second month of Ttumjāara', i.e. an intercalary month of the lunisolar calendar (cf. e.g. Hedin 21.5 and 24.4). If 1.1 opened, as is likely, with [hamd]y[a]j[ä] $\mathrm{m}[\bar{a} s)_{\mathrm{t}}[\ddot{a}]$ 'in the month of Hamdyaja', then the account began with the first summer month. A few slips may be corrected: read a8 kūsa 4 kha 2 ' 4.2 kūsas' for kūsa 5 kha 2 ' 5.2 küsas'; a10 'in the month of Bramkhaysja' is omitted in the translation; read a13 nāte for nate; read b2 lāhurā for lāhurāmj; in the translation read a13-14, b2, b7-9 '0.3 kūsa' etc. instead of ' 3 kūsas' etc., and b1 '0.5 kūsa' instead of ' 5 kūsas'.

INDEX

Thèmes : 2.1. Langues anciennes 


\section{AUTEURS}

MAURO MAGGI

Università di Napoli « L'Orientale » 